\title{
Teacher and learner beliefs and expectations about English language teaching and learning at a Mozambican university
}

\author{
Marcos Abilio Nhapulo \\ Faculdade de Letras e Ciências Sociais, Universidade Eduardo Mondlane \\ Mozambique
}

\begin{abstract}
Recent studies have suggested that teacher and learner beliefs about second language instruction have a significant influence on language teaching and learning process and, consequently, on students' achievements. However, in the Mozambican context, we still do not have studies focusing on learner and teacher beliefs about students and language proficiency, about teaching materials, about individual and cultural variations and beliefs about the learning process itself. Using questionnaires and a focus group report, we look at the Mozambican linguistic profile, the learner and teacher beliefs and their influence in tertiary English Language Teaching (ELT) and learning. The results show that there is a need for creating an environment in which teachers' and learners' cultural background, beliefs and needs are considered so as to enable teachers to teach effectively, as well as enabling learners to achieve positive learning outcomes.
\end{abstract}

Key words: beliefs, expectations, English Language Teaching, Mozambican students, Mozambique, second language learning

\section{Introduction}

The current research was conducted among English language students and teachers at UEM and it was designed to ascertain student and teacher beliefs about students and language proficiency, beliefs about teaching materials, beliefs about individual and cultural variations and beliefs about the learning process itself, taking into consideration that instructional decisions and the selection of teaching materials and practices as well as learning practices are mostly influenced by teachers' and learners' beliefs. The study derives from the fact that instructional decisions and the selection of teaching resources and practices as well as learning practices are mostly influenced by teacher and learner beliefs. That is, "second or foreign language students may hold strong beliefs about the nature of the language under study, its difficulty, the process of its acquisition, the success of certain learning strategies, the existence of aptitude, their own expectations about achievement and teaching methodologies", (Bernat \& Gvozdenko, 2005:I). The relevance of this study 
stems from the fact that understanding teachers' beliefs is also understanding teachers' classroom practices (Brown, 2009), since their actions are highly affected by their beliefs about language teaching and learning, (William \& Burden, 1997). Likewise, understanding students' beliefs is also to grasp their reaction in the classroom learning environment, since dealing with learners' beliefs is tackling an issue that has been considered as fundamental to their academic progress (Horwitz, 2008).

In addition, it is important to note that this article focuses on General English (or ELT in general) and not on English for Academic Purposes (EAP). That is, at UEM we have ELT rather than EAP courses, which are aimed at training students to become English language teachers. In many countries, EAP courses are mostly offered by Institutes and Language Centres attached to universities and they are generally targeted to non-native English speakers who are willing to carry on with their studies at the university level. In Mozambique, there is still a need to develop an effective EAP course for students and university lecturers to be prepared to sit for IELTS or TOEFL exams whenever they want to upgrade their academic degrees to Masters and PhD in English speaking countries. Generally speaking, EAP is demanding (Cummins ( $198 \mathrm{Ib}$, cited in Adjer et al, 2002), always matched to learners' requirements, needs and goals, Gillet (1996) and it relies on broad knowledge, understanding and interpretation.

At University Eduardo Mondlane - UEM, all courses have English I during the first semester of their first year. For most of the courses this English I is a sort of English for Specific Purposes (ESP), since it is aimed at enabling students to deal with technical terms of their fields of study. For the students involved in this study, English lessons are divided in semesters, from English I (semester I) to English VIII (semester VIII). These are ELT classes in which the teaching materials/resources are diverse. Most of the material used in the classroom is not locally produced, but imported from the US, UK, Australia and other English speaking countries. These books include scientific articles, journals, (creative) reading books, newsletters, magazines, grammar and vocabulary books, dictionaries, and several academic books found in the libraries.

\subsection{Mozambican historic and linguistic background}

In The Battle of the Languages (Lopes, 2004) it is noted that today's Mozambique is the result of different linguistic and cultural influences. Arabs were the pioneers in the VIII century, followed by Indians, Chinese and Indonesians, before Portuguese colonization started at the end of the XV century. Portuguese has been used as the official language since 1975 , the year of independence, but there are many unofficial Bantu languages that are used throughout the country, as well as Asian languages (Gujarati, Memane, Hindi and Urdu). An inquiry conducted by the National Education Institute (1998, cited in Lopes, 2004) notes that the Bantu languages most widely spoken in Mozambique are: Emakhuwa, Xitsonga (Xichangana), Cisena, Elomwe, Echuwabo, Cishona, Xitswa, Xirhonga, Cinyanja, Cinyungwe, Cicopi, Ciyao, Shimakonde, Gitonga, Ekoti, Kimwani, Kiswahili, Swazi, Cisenga, and Zulu. So, there are about 27 languages in Mozambique: 20 Bantu languages, 4 Asian languages, 3 European languages (Portuguese, English and French). 
The last two languages are compulsory subjects from primary and secondary school onwards, respectively. There are more than 6 languages (English, French, Spanish, Italian, Arabic and Chinese) that can be added to the abovementioned 27 languages, totalling 33 languages (including several dialects).

In 1975 , in the $\mathrm{I}^{\text {st }}$ National Meeting on Information, the role of Portuguese was stressed as the language for national unification, instruction and the national language of wider communication and the use of Bantu languages in the domestic environment and in community radios was underlined. In 1979 there was the ist National Seminar on Portuguese Language Teaching in which participants talked about the need of investigating the Bantu languages.

Bantu languages did not have corpus language planning till the $\mathrm{I}^{\text {st }}$ Seminar of Harmonization of the Orthographies of Mozambican Languages held in 1987 by NELIMO (Mozambican Languages Studies Centre), with the purpose of establishing official orthographic systems for each national language, so that all of them could have similar orthographies (Firmino, 2005). It was only recently that the National Institute of Education Development started "An Experience of Bilingual Education in Mozambique" project, which had to do with bilingual education in primary schools. This program was introduced in 2003, involving I6 Bantu languages and 15,000 students from all the Io provinces. Students were supposed to use only a Bantu language up to grade 3 and from grade 4 to 5 , they had to use both their Lr and Portuguese as L2. The previous project, Bilingual Schooling Project in Mozambique (I993 to I997) had shown methodological problems, since initially teachers used the same methodologies for both the LI and the L2. This is why the new program introduced in 2003 was basically installed to improve the quality of education since it became much easier for students to learn in their mother tongues and then transfer their abilities to the L2. The program also motivated students to stay at school, reducing the number of students who gave up school because of the exclusive use of the L2. All these steps showed that linguistic revitalization and cultural valorisation derived from LI use raises students' self-esteem as well (Chimbutana, 2003). However, even when steps have been taken for Bantu language revitalization, Lopes (200I) points out that among the new generation Portuguese seems to hold sway over any Bantu language.

\subsection{The current status of English in Mozambique}

According to Dias (1998), French and English are considered foreign languages, although in this study we refer to English as a second language, since it is also used as an official language in the SADC ${ }^{\mathrm{I}}$, side by side with Portuguese. However, at SADC meetings, when it comes to actual practice, English is used exclusively as the official language (Lopes, 2004). Taking into consideration that Mozambicans need English to communicate with their neighbouring countries, English was introduced into the Mozambican Education System some decades ago and now it is being taught from grade 6 onwards.

I South African Development Community 
Before independence, in 1975, English was taught from the secondary school level on. Since Mozambique became part of the SADC and Commonwealth community, English has been taught not only at schools, but in other public and private institutions throughout the country. The shortage of skilled teachers, low salaries, as well as a lack of materials have been pointed out as the problems English teaching faced in the 8os (Dias, 1998), and some of these problems are still the reason for students' weaknesses today. The few skilled teachers prefer working in private institutions to public ones, because usually the private sector pays higher salaries and has better working conditions.

Therefore, for those who do not have enough money to pay for private schools, to access the internet and to buy learning materials - which is the majority of Mozambicans - there is little chance of achieving a high level of linguistic competence, with the exception of those who are already involved in self-directed learning activities (Wenden, 2002) and resource centres. Nowadays, with many public and private teacher training universities and centres in Mozambique, there are more and more schooling alternatives. It is important to note here that there are language schools almost everywhere, mainly in urban areas. Some suburban dwellers point out that there are also quality teachers in the urban belt neighbourhoods (Nhapulo, 20II). However, what students are supposed to master does not always match their learning outcomes, because students entering university, a Master or a PhD program stilllack the English language skills required for academic purposes.

Although there are no official figures showing the numbers of English language speakers in Mozambique, it is currently spoken in elite and rich families, among those families whose children study at schools which use English as the language of instruction or among those parents who are willing to send their children to study abroad. Speaking English is also associated with a higher status, which is why it is sometimes used simply to display one's social prestige (Firmino, 2005). The only place in the whole country where two in four young people speak English is at the KaMubukwana District (at Inhagoia), where English feeds the youth entrepreneurial spirit and it is used for normal social interaction and not for showing higher social status as such (Nhapulo, 2011).

In Mozambique (and most likely in other multilingual countries too), what teachers and students believe determines their learning strategies and teaching practices in general (Baiyinna, 200I). Therefore, it is important to know what beliefs and expectations teachers and, especially, learners bring into the classroom setting, since the perceptions, beliefs, attitudes, and metacognitive knowledge that students bring with them to the classroom has a significant influence on the learning process and ultimate success Breen (200I, cited in Bernat \& Gvozdenko, 2005). This study, then, will focus on the following question: What are teacher and learner beliefs about language teaching and learning in the Mozambican context?

\subsection{Learner beliefs in language learning research}

Learner beliefs are generally what learners bring into the classroom learning environment which may be based on their cultural background or even their learning experience. Beliefs studies depend on the kind of the inquiry undertaken by the researcher. 
While some studies employ interviews and focus groups (Wenden, 1987), others use an inventory of belief statements to which learners have to react by showing their level of agreement (Horwitz, 1987). In order to gather most of the required information, the current study employs both approaches. Following Barcelos (cited in Bernat \& Gvozdenko, 2005), and (Bernat \& Gvozdenko, 2005), we can identify the following broad three approaches considered in research on beliefs:

- a) The Normative Approach: studies under this approach are characterized by the use of a Lickert-scale questionnaire and most of them derive from the BALLI - Beliefs About Language Learning Inventory (Horwitz, 1985). Findings from these studies have shown that learner beliefs about language learning are sometimes related to a specific context, which is the reason why there are differences depending on the linguistic background of the students. The most important aspect is that these studies support the idea that understanding learner beliefs can enhance the language learning process, enabling L2 learners to deal effectively with the classroom tasks and the learning environment as a whole, (Chawhan \& Oliver, 2000; KimYoon (2000); and many other studies to be found in Horwitz, (1999));

- b) The Metacognitive Approach: most of the studies conducted under this approach can be related to Wenden (1986a, I986b, I987, I998, I999, 2001). The study conducted in 1987 by this author showed that learners had the following prescriptive beliefs: the relevance of using English in a more natural way, learning grammar and individual factors derived from individual differences. The general aspect under this approach is that learners become aware of their learning styles, learning strategies and beliefs, and this enables them to deal with the learning process and environment effectively.

- c) The Contextual Approach: this approach uses ethnography, narratives, and metaphors (Kramsch, 2003), and it is conducted within a given context. These studies are more qualitative and they are used to make specific and general interpretations, the reason the instruments used include diaries (Hosenfeld, 2003), interviews (White, 1999), discourse analysis (Kalaja, 2003), informal discussions (Allen, I996; Barcelos, 2000,) among other tools.

As we can see, our current study directly employs both the normative and the contextual approach, and indirectly the metacognitive approach. It is because of the existence of these approaches which are complementarily linked that we have the notion of beliefs as the assumptions learners hold about themselves, factors that influence the learning task itself, as well as the nature of language learning and teaching as a whole (Riley, 1980; Victori \& Lockhart, 1995), insights (Omaggio, 1978), conceptions of learning (Benson \& Lor, 1999), psychologically held understandings or assumptions about the world and which are felt to be true (Yang, 1999; Richardson, cited in Peacock, 2001), among other conceptualizations. These several notions of learner beliefs show that there are many factors to be considered when dealing with the issue of learner beliefs in general. 
In fact, Dogancay-Aktuna (2005; p. 99) noted that "teachers need to consider to what extent the underlining principles of their chosen methodology will correspond with the set of assumptions that learners bring to the classroom". This shows that beliefs and expectations learners bring into the classroom should be known and considered to avoid misunderstandings.

In this context, the process of teaching and learning a language shows that teachers and learners have beliefs that may influence negatively or positively their teaching practice and their learning strategies which, in turn, may influence both their teaching performance and learning achievements in general. So, talking about teacher and learner beliefs is talking about pedagogical beliefs, classroom teaching practices, as well as learner understandings of the language learning process, their opinions of their roles, including factors influencing the language learning and the nature of the language teaching and learning processes (Baiyinna, 20II).

Although we may have general aspects viewed through general psychometric measures such as intelligence or aptitude (Thomas \& Harri-Augustein, 1983), what seems to be obvious is that learner beliefs are related to individual differences in language learning and, in this regard, personality, self-concept, identity, and even motivation and the Confucian concept of losing face common among Chinese students (Cortazzi \& Jin, 2006) are among the intertwined factors. Also, Richards (1996, cited in Baiyinna, 2011:95) suggests that there are teachers' belief systems which have different sources such as their own experience as language students, established practice, personality factors, and education-based or research-based principles. Like teachers, learners have personality and cultural factors that have an impact on their learning process as a whole. Failure to consider their cultural background can lead to a distorted viewpoint of the learners' culturally in-built abilities.

So far we can see that there are several factors related to learner and teacher beliefs about language learning and teaching, and one of the factors to be underlined is the student's and teacher's cultural background. That is, considering that culture influences significantly the manner in which one learns how to learn (Brislin \& Yoshida, 1994), beliefs are likely to influence motivation and language learning performance as well as learning strategies, (Sakui \& Gaies, 1999). In fact, culture involves "frameworks of expectations, attitudes, values and beliefs about what constitutes good learning, about how to teach or learn, whether and how to ask questions, what textbooks are for, and how language teaching relates to broader issues of nature and purpose of education", Dogancy-Aktuna (2005:99) or settled frameworks of rules, beliefs, attitudes and values, which are to be considered as crucial elements in language learning and teaching, as well as in learning styles, Biggs \& Moore (1993, cited in Kennedy, 2002).

Talking about learning styles is somehow looking at culture in its personalized perspective. That is to say, in L2 learning individuals have differences which may be related to sensory preferences, personality types, desired degree of generality, and biological differences, referred by Oxford (2003, cited in Bernat \& Gvozdenko, 2005) as the four dimensions of learning style that are likely to be among those most strongly associated 
with L2 learning. Considerir.g the fact that learning is achieved at different dimensions we can look at learning styles from different perspectives: we can see them as different ways used by learners to process and organize information or to react with a learning environment (Shuel, I986), as a way of thinking, comprehending and processing information (Jensen, 1998) or a psychological trait that serves as an indicator of how one perceives and interacts in the learning environment (Darlene, 1997).

Furthermore, considering that the success of a curriculum may depend on the fact that learner characteristics, interests, abilities, experience (Yilmaz-Soylu \& Akkonyulu, 2002), as well as beliefs, are considered in its design and implementation, we can see that individual learning styles also needs a theoretical critical attention in curriculum design and a practical personalized attention in teaching practice. If we take into account that teachers might play a central role in promoting tolerance and mutual understanding among learners of different cultural backgrounds Prat (1999, cited in Kennedy, 2002), we can see that not only learners' beliefs and expectations, but also those of teachers deserve critical attention in language teaching. So, we can conclude that there is a link between beliefs, culture and learning styles, considering that one learns better when his/ her beliefs and expectations are mirrored in the classroom setting, when his/her cultural background is taken into consideration, and when s/he is taught in his/her learning style Sandhu (1995, cited in Darlene, 1997).

Last but not least one factor to be considered while dealing with learner beliefs has to do with the teaching practice. When a teacher believes in a type of classroom teaching practice (Williams \& Burden, 1997), s/he will keep on following that practice for a period of time, although beliefs are also dynamic, which is why they vary according to a given person, context and time. Context may or may not enable the implementation of a given teaching practice which, in turn, depends on the beliefs and expectations teachers and learners have about the language teaching and learning processes. Therefore, it seems very important to take into consideration teachers' beliefs in pedagogical decisions and instructional materials choices, for the improvement and the benefit of the teaching practice itself. 


\section{Methodology}

\subsection{Setting and Participants}

\begin{tabular}{|c|c|}
\hline Elements & Profile \\
\hline UEM Students & $\begin{array}{l}40 \text { students: } 20 \text { Portuguese/English Translation and Interpreta- } \\
\text { tion Course students and } 20 \text { ELT Course students; Students (aged } \\
\text { between } 20 \text { and 30) from all the Io Mozambican provinces. 3rd } \\
\text { academic year, English 5, Ist semester (2012); Students (aged } \\
\text { between } 20 \text { and 30) from all the Io Mozambican provinces; } \\
\text { Students have different mother tongues and studied English for } \\
5 \text { years before entering university. }\end{array}$ \\
\hline Courses & $\begin{array}{l}\text { Portuguese/English Translation and Interpretation: the course } \\
\text { deals with linguistics in general, but the core issues are related } \\
\text { to translation theory. Students majoring in translation become } \\
\text { English teachers and translators. } \\
\text { ELT: the course deals mostly with applied linguistics and it in- } \\
\text { volves teaching methodology, curriculum design. Unfortunately, } \\
\text { the course doesn't have contents related to Learning Strategies. } \\
\text { After this course students become English language teachers in } \\
\text { secondary schools. }\end{array}$ \\
\hline UEM Teachers & $\begin{array}{l}\text { Io teachers: } 8 \text { Mozambican and } 2 \text { foreign teachers, all of them } \\
\text { teaching at UEM at the English Section. More than } 3 \text { years of } \\
\text { teaching experience. }\end{array}$ \\
\hline University & University Eduardo Mondlane - UEM (public university). \\
\hline Classroom & $\begin{array}{l}\text { Teaching materials available in the classrooms. } \\
\text { Not well-equipped classrooms. No Internet access during } \\
\text { classes. }\end{array}$ \\
\hline Teaching $\mathrm{r}$ & from different sources used in class. \\
\hline
\end{tabular}

Table 1: Participants' profile 


\begin{tabular}{l|l}
\hline Seating arrangement & Classroom Profile \\
& $\begin{array}{l}\text { Students seated in pairs, facing the teacher. Students } \\
\text { self-selected seating. Groups were mixed-gender and } \\
\text { not teacher determined. Group membership changed } \\
\text { according to given exercises and group members } \\
\text { elected a leader. }\end{array}$ \\
\hline Class interaction & $\begin{array}{l}\text { Teacher direct questions to individual students or } \\
\text { groups. These groups create a competitive atmosphere } \\
\text { which is specific to individualistic cultures, although } \\
\text { this is not typical to Mozambican students who are not } \\
\text { always competitive. }\end{array}$ \\
\hline Materials & $\begin{array}{l}\text { Teacher did not follow a set course or use the textbook } \\
\text { closely and they also used many published materials in } \\
\text { lessons. }\end{array}$ \\
\hline Mothod of Interaction) & $\begin{array}{l}\text { Students are always encouraged to use L2 in their class- } \\
\text { room interaction. Li use only when L2 words are similar } \\
\text { to a Bantu language or to Portuguese. }\end{array}$ \\
\hline Participation & $\begin{array}{l}\text { If students do not put their hands up to answer, the } \\
\text { teacher may single them out to respond. Students like } \\
\text { volunteering to answer questions. }\end{array}$ \\
\hline Error Correction & $\begin{array}{l}\text { Regular feedback on errors. An emphasis on correct } \\
\text { pronunciation. Errors are corrected after each group has } \\
\text { attempted the task. }\end{array}$ \\
\hline $\begin{array}{l}\text { Individual students are responsible for their own learn- } \\
\text { ing. Students were expected to share responsibility for } \\
\text { learning outcomes and group leaders acted as repre- } \\
\text { sentatives. }\end{array}$ \\
\hline Setial
\end{tabular}

Table 2: Classroom profile

The fact that we have this classroom profile does not mean that the same profile is to be found in all Mozambican classrooms. This classroom was chosen because of its representative nature and both the involved classes had the same profile as presented in this table. Most of the classrooms at the UEM have this profile but seating arrangement, class interaction, MOI and error correction vary from one class to another. This is due to differences in teachers teaching experience, the way desks are arranged in the classroom, and whether or not the teacher speaks a Bantu language and/or Portuguese.

Another aspect of the university classrooms is the large number of students in a class which sometimes does not enable self-selection in seating and group work. Group identities can vary according to gender, province or region of provenance of the students, work experience shared among students, among other factors. These are some of the reasons why some teachers prefer choosing group members. 


\subsection{Instruments}

At the beginning of the study the researcher observed both courses involved in this study over the course of two lessons. This enabled him to draw the participants and the classroom profiles presented in the two tables above. Then, considering that in order to study learner and teacher beliefs, it is necessary to use an instrument which enables them to self-report their attitudes and express their perceptions about themselves and the teaching and learning processes in which they are involved, all of the participants completed a two-page questionnaire and all the responses were relevant for the study. The questionnaire had two sections: 20 questions about beliefs about students and learning and 20 about beliefs about teachers and learning. The 40-item questionnaire employed a four-point Likert Scale where $\mathrm{I}=$ strongly disagree, 2 = agree, $3=$ disagree and $4=$ strongly agree. We have used a four point Lickert scale and not a five point scale because the four points enable us to look only at the agreement and disagreement which is what we aim to find out directly in this questionnaire.

Questionnaires for the teachers were placed at the English Section office with instructions on how to fill in and return them to the researcher. The questionnaires for students were distributed in both the English language Teaching class and the Portuguese/English Translation/Interpretation class and returned to the researcher after a week. All 40 questionnaires were returned and were valid for this study.

Before being given questionnaires, the involved students were firstly involved in a Focus Group interview with questions related to the dimensions of the questionnaire used in this study. The researcher took notes while students commented on the questions below. Firstly, the comments were made in four groups, each with its question, and then as a whole class. The answers for these questions were a sort of a self-report done by the four groups
a) Are you satisfied with the learning materials you use?
b) How can the materials be improved to fit your needs?
c) Are your teachers always available in and outside the classroom environment?
d) Are the teachers authoritative or friendly in the class?

The question a) is relevant in that it gives an insight into what students think about the material they are using, taking into account that there is shortage of teaching material in the Mozambican Education System as a whole, and particularly at universities. Question b) is important because it enables us to look at what students think should be the required improvements according to their needs and expectations. Question c) is necessary because some students expect the teachers to be available and help them outside the classroom but some students and teachers believe that teachers should only be available in the classroom setting. With the turbo phenomena, Mozambican teachers tend to have less time for students outside the classroom. Question d) refers to the way teachers interact with their students, particularly inside the classroom learning environment. 
While groups were reporting on their question and drawing from the previous discussion the whole class had had, the researcher took notes, and this is the reason why in the following section, Results and Discussion, we have information derived from two sources: the questionnaires and the focus group comments on teaching and learning practices. Below are the focus group answers to the four questions discussed in the classroom:

- a) Many students stated that they are satisfied with the material they use but they still think that there is still more material that should be considered during the four years of our course. Shortage and sometimes even lack of didactic material is a problem when it comes to homework and assignments. There is a lack of community libraries or resource centres where they can go to practice what they learn.

- b) Some students think that our material should include more issues about Mozambique and Mozambican studies and cultural elements should be used as examples during lectures. They are at university so as to understand their culture, tradition, not only science in general. Most of the books they have in libraries do not dealing with current issues. They should use current articles rather than old books.

- c) Teachers are not always available outside the classroom. Some teachers work at many universities and they only go to the UEM as part-time teachers. They are only available during classes. If you need to meet them, you need to make an appointment some days before. They are very busy with something else, the reason why students just don't know what makes them so busy. Sometimes one teacher has more than 3 classes and s/he teaches during the day and the night shift as well.

- d) All students stated that they have both authoritative and friendly teachers. Sometimes it has to do with the influence of the culture from the countries where teachers do their Masters and $\mathrm{PhD}$ programs. Egalitarian societies like Australia tend to have friendly teachers. It has also to do with teachers' past experience and a personality issue, such as when a teacher is proud and authoritative, just because he had teachers who were proud and authoritative in the past, especially during the colonial period.

Moreover, it is important to note that there was no pilot testing of the questionnaire due to students' availability. Another issue which can be observed in table 4 below is that there are two dimensions with few items: individual and cultural variations and teachers and learning. The apparent shortage of items in these dimensions is covered by the focus group discussion, since most of the issues raised by this group replaced items which could have been part of the questionnaire. That is, the focus group was open to talk about cultural issues and how teachers deal with learning orally, than in a written form, and this was also the way the researcher saw as most effective for collecting data on these two dimensions. Considering that qualitative data are also important in questionnaire validity (Damato et al., 2005; Dornyei, 2002) we have used more qualitative than quantitative data for both the aforementioned dimensions. 


\begin{tabular}{l|l|c|l|c} 
Dimensions & \multicolumn{3}{|c}{ Item Number } \\
\hline Beliefs about & $\begin{array}{l}\text { Students \& } \\
\text { Learning }\end{array}$ & Items & Teachers \& Learning & Items \\
\hline $\begin{array}{l}\text { Students' language } \\
\text { proficiency }\end{array}$ & I, 2, 5, 8, I3 & 5 & I3, I6 & 2 \\
\hline $\begin{array}{l}\text { Development of teach- } \\
\text { ing/ learning materials }\end{array}$ & I4, I8, 20 & 3 & $\begin{array}{l}\text { I, 3, 4, 6, 7, 8, I4, I5, } \\
\text { I8, I9 }\end{array}$ & I0 \\
\hline $\begin{array}{l}\text { Individual and cultural } \\
\text { variations }\end{array}$ & I7 & I & 5, I7, 20 & 3 \\
\hline $\begin{array}{l}\text { Students and learning } \\
\text { 3, 4, 6, 7, 9, I0, }\end{array}$ & 9 & 2,9, I2 & 3 \\
\hline Teachers and learning & I6, I9 5 & 2 & I0, II & 2 \\
\hline Total & & $\mathbf{2 0}$ & & 20
\end{tabular}

Table 3: Five dimensions of the questionnaire and their item numbers (See Appendix below).

\section{Results and Discussion}

The results are presented according to the five dimensions observed in this study: students' language proficiency; development of teaching/learning material; individual and cultural variations; students and learning and teachers and learning. In the tables below we have the total number of those who agree (strongly agree and agree) and those who do not agree (strongly disagree and disagree) with the questionnaire statements. Then a percentage of the total number of students and teachers is calculated so as to see how they consider the statement within each dimension. 


\begin{tabular}{|c|c|c|c|c|c|c|c|c|c|}
\hline $\mathrm{N}^{\circ}$ & Statement & & & & Freq & lenc & & & \\
\hline & & & Total & gre & & & Total D & sag & \\
\hline & & S & $\%$ & $\mathrm{~T}$ & $\%$ & $S$ & $\%$ & $\mathrm{~T}$ & $\%$ \\
\hline I & $\begin{array}{l}\text { Mozambican students speak } \\
\text { more than one language. }\end{array}$ & 34 & 85 & 9 & 90 & 6 & 15 & I & IO \\
\hline 2 & $\begin{array}{l}\text { Mozambican students are good } \\
\text { English language learners. }\end{array}$ & I6 & 40 & 8 & 80 & 24 & 60 & 2 & 20 \\
\hline 5 & $\begin{array}{l}\text { Students are good at grammar } \\
\text { but they are not fluent in } \\
\text { speaking. }\end{array}$ & 25 & 62.5 & 5 & 50 & I5 & 37.5 & 5 & 50 \\
\hline 8 & $\begin{array}{l}\text { Students are bad at reading } \\
\text { and writing. }\end{array}$ & 20 & 50 & 4 & 40 & 20 & 50 & 6 & 60 \\
\hline $\begin{array}{l}\mathrm{I} 3 \\
(\mathrm{ST})\end{array}$ & $\begin{array}{l}\text { Students rely on copy and paste } \\
\text { techniques when doing reading } \\
\text { exercises. }\end{array}$ & 3 & $7 \cdot 5$ & 6 & 60 & 37 & 92.5 & 4 & 40 \\
\hline $\begin{array}{l}\text { I3 } \\
(\mathrm{T})\end{array}$ & $\begin{array}{l}\text { Teachers should encourage stu- } \\
\text { dents to be increasingly autono- } \\
\text { mous, i.e. to facilitate student } \\
\text { independence as learners. }\end{array}$ & 34 & 85 & IO & 100 & 6 & I5 & 0 & 0 \\
\hline I6 & $\begin{array}{l}\text { Teachers think that students } \\
\text { have fewer opportunities for } \\
\text { practicing their speaking skills. }\end{array}$ & 29 & 72.5 & 8 & 80 & II & 27,5 & 2 & 20 \\
\hline
\end{tabular}

Table 4: Beliefs about students and learning

The majority of teachers (90\%) and students (85\%) agree that most Mozambican students are from diverse linguistic backgrounds and most of them speak more than one language. Recent studies have shown that when students use their mother tongue as the language of instruction in earlier classes they will later transfer their linguistic abilities when learning a second language. In fact, mother tongues need to be revitalized because their use as medium of instruction enables learners to achieve positive learning outcomes and its use also enables learners to deal with their daily life events efficiently (Skutnabb-Kangas, 2002; UNESCO, 2003, Benson, 1997). However, students involved in this study are at a disadvantage because they did not have that opportunity. In spite of that, $80 \%$ of teachers believe that Mozambicans students are good English language learners. Surprisingly, only $40 \%$ of the students believe that they are good language learners, and this may be related to their interpretation of past language learning experiences (Kern, I995), considering that before university, these students had about 5 years of English language lessons. 
Looking at language skills, we can see that only half of the students $(50 \%)$ believe that they are bad at reading and writing. Most of the students $(62.5 \%)$ believe that they are good at grammar but that they are not fluent speakers. This shows that there is lack of opportunities for students ( $72.5 \%$ ) to practice their speaking skills. Also, lack of Reading Strategy Instruction as such may be the reason why students do not have good reading and also writing skills. Although there is a lack of effective reading strategies awareness, students $(92.5 \%)$ maintain that they do not rely on copy and paste techniques when doing reading exercises. However, there are cases in which students simply go back to the test and see where there are words that are similar to the ones in the question and then copy the passage, without even rereading it to make possible changes.

So, in order to improve the ability of using the English language, students need some form of coaching to help them gradually become independent learners. That is why students $(85 \%)$ believe that teachers should encourage them to learn in a more autonomous way. For this to be possible, students need to make sure they find resource centres, libraries where they can go and practice their skills.

\begin{tabular}{c|l|c|c|c|c|c|c|c|c}
$\mathrm{N}^{\circ}$ & Statement & \multicolumn{7}{|c|}{ Frequency } \\
\hline & \multicolumn{1}{|c|}{ Total Agree } & \multicolumn{3}{c}{ Total Disagree } \\
\hline I4 & $\begin{array}{l}\text { Mozambican students speak } \\
\text { more than one language. }\end{array}$ & 30 & 75 & 7 & 70 & I0 & 25 & 3 & 30 \\
\hline I8 & $\begin{array}{l}\text { Students decide on what to learn } \\
\text { at the beginning of the semester. }\end{array}$ & 0 & 0 & 5 & & 40 & I00 & 5 & 50 \\
\hline 20 & $\begin{array}{l}\text { Teachers change their teaching } \\
\text { materials whenever they wish so. }\end{array}$ & 20 & 50 & 9 & 90 & 20 & 50 & I & I0 \\
\hline I & $\begin{array}{l}\text { Mozambican teachers should } \\
\text { develop teaching materials } \\
\text { considering the existing simi- } \\
\text { larities between Portuguese and } \\
\text { English. }\end{array}$ & 30 & 75 & 5 & 50 & I0 & 25 & 5 & 50 \\
\hline 3 & $\begin{array}{l}\text { Mozambican teachers should } \\
\text { develop teaching materials con- } \\
\text { sidering the existing similarities } \\
\text { between Bantu Languages and } \\
\text { English. }\end{array}$ & $2 \mathrm{I}$ & 52.5 & 3 & 30 & I9 & 47.5 & 7 & 70 \\
\hline 4 & $\begin{array}{l}\text { Teaching material has to be } \\
\text { culturally contextualized. }\end{array}$ & 26 & 65 & 9 & 90 & I4 & 35 & I & I0 \\
\hline 6 & $\begin{array}{l}\text { The materials I use in the class- } \\
\text { room are suitable for Mozam- } \\
\text { bican advanced students. }\end{array}$ & 9 & 22.5 & I0 & I00 & 31 & 77.5 & 0 & 0 \\
\hline
\end{tabular}




\begin{tabular}{c|l|c|c|c|c|c|c|c|c}
$\mathrm{N}^{\circ}$ & Statement & \multicolumn{7}{|c}{ Total Agree } & \multicolumn{3}{c}{ Total Disagree } \\
\hline & \multicolumn{1}{|c|}{ Srequency } \\
\hline 7 & $\begin{array}{l}\text { Teachers may use Portuguese, } \\
\text { English or any Bantu language, } \\
\text { so long as students can un- } \\
\text { derstand what they are being } \\
\text { taught. }\end{array}$ & 30 & 75 & 7 & 70 & I0 & 25 & 3 & 30 \\
\hline 8 & $\begin{array}{l}\text { Teachers should teach English } \\
\text { only through English. }\end{array}$ & 20 & 50 & 6 & 60 & 20 & 50 & 4 & 40 \\
\hline I9 & $\begin{array}{l}\text { Teachers expect students to } \\
\text { speak only in English in the } \\
\text { classroom. }\end{array}$ & 39 & 97.5 & 6 & 60 & I & 2.5 & 4 & 40 \\
\hline I5 & $\begin{array}{l}\text { Mozambican teachers should de- } \\
\text { velop teaching material consid- } \\
\text { ering the students current level } \\
\text { of proficiency. }\end{array}$ & 40 & I00 & I0 & I00 & 0 & 0 & 0 & 0 \\
\hline I8 & $\begin{array}{l}\text { It doesn't matter what materials } \\
\text { teachers use as long as the level } \\
\text { is suitable for their students. }\end{array}$ & 33 & 82.5 & 7 & 70 & 7 & I7.5 & 3 & 30 \\
\hline I4 & $\begin{array}{l}\text { Teachers partake in curriculum } \\
\text { design and implementation. }\end{array}$ & I0 & 25 & 8 & 80 & 30 & 75 & 2 & 20 \\
\hline
\end{tabular}

Table 5: Beliefs about development of teaching/learning material

The fact that most students ( $75 \%$ ) believe that teachers have to give them the material they need in the classroom is another stumbling block for the improvement of students' linguistic skills. Although there is shortage of learning materials ${ }^{2}$ in the libraries, and students rely on the materials teachers provide them with in the classroom, they do need to make an effort so that they do not depend wholly on the material given by the teacher. Fortunately, there is wireless connection around the main campus and students can research online, but not all of them have computers. Here, if students continue to expect the teacher to give them everything in the classroom, they will be limited, given that not all teachers are capable of finding up-to-date information in their field of research. That is, research moves forward day after day and it is not effective for university teachers to use the same material they have used more than 5 years ago without making necessary changes, so as to include current research trends.

There are few cases in which teachers ask students about the type of evaluation they would like to have during a semester, but generally students do not decide on what to

2 As we can see in the Instructions section, where the Focus group answers $a$ and $b$ show lack of materials. 
learn at the beginning of the semester. Teachers bring their materials in the classroom and they change them whenever they wish to. The important point is that the materials teachers use in the classroom, should be in accordance to the proper curriculum, syllabus and the learners' current level of proficiency as has been the case to date. These materials should fit to learners' linguistic competence and they should be culturally contextualized, as students (65\%) and teachers (90\%) agree on this statement. They also agree on the inclusion of the existing similarities between Portuguese and English and between Bantu Languages and English in the produced materials, although the majority of teachers (75\%) and students (50\%) as shown in points I and 3, think that consideration of Portuguese's similarities is better than that of the Bantu languages (52\% students and $30 \%$ teachers). However, if a Bantu language is used in the classroom, then it is effective to do a translation into English, as not all learners speak the same Bantu language.

Historically in Mozambique teaching English was mostly conducted through English (as we can see in the agreements on the statements 8 and 19), since the first English teachers were almost all native speakers (Lopes, 1997). This interaction method may be used profitably in advanced classes like those involved in this study. However, if it is used at lower English levels, it may lead to a steady decrease in the desired learning outcome. Furthermore, it is important to note that when English was taught during the first years, there were no originally Mozambican textbooks and teachers. It is only recently that we can find trained teachers and textbooks that are culturally rooted in the Mozambican context, which means that teaching materials also have to focus on the local realityand thus take into consideration the students' and teachers' cultural backgrounds. In fact, it is more effective to use Mozambican textbooks and dictionaries (Sitoe \& Schulz, 2005), than importing these materials. While using these materials, point 7 makes sense here, teachers may use English as is evident in this study, but they may also use Portuguese and a Bantu language if the reality they want to express is well perceived in these languages.

In sum, "teachers need to consider to what extent the underlining principles of their chosen methodology will correspond with the set of assumptions that learners bring to the classroom", (Dogancay-Aktuna, 2005). Drawing from this author, we can see that teachers and the curriculum designers have to take into consideration teaching methodologies which fit multicultural classrooms. That is, it is not only the order in which syllabuses are applied should be a matter of attention, but also methodologies used in the teaching practice should fit a learner's language competence performance, learning styles, beliefs and expectations. As a matter of fact, (Field, 2000:14), states that "good practice involves the sharing of ideas and a flexibility of approach enabling a meeting of pupil's and society's needs". Moreover, the design of L2 curricula and the teaching methodologies in Mozambique (and elsewhere) should not only value the learner's cultural background and use the target language's cultural aspects as classroom language content, but it should also enable learners to acquire knowledge of cultural differences. Regarding this issue, Lopes (1997:68) noted that Mozambican "learners should, in their process of learning a language, understand language but also acquire an ability to identify with, understand and accept others and their culture". 


\begin{tabular}{c|l|c|c|c|c|c|c|c|c}
$\mathrm{N}^{\circ}$ & Statement & \multicolumn{3}{|c|}{ Frequency } \\
\hline & & $\mathrm{S}$ & $\%$ & $\mathrm{~T}$ & $\%$ & $\mathrm{~S}$ & $\%$ & $\mathrm{~T}$ & $\%$ \\
\hline I7 & $\begin{array}{l}\text { Students' cultural background is } \\
\text { considered in curriculum design. }\end{array}$ & I0 & 25 & 3 & 30 & 30 & 75 & 7 & 70 \\
\hline 5 & $\begin{array}{l}\text { Student independence is to be } \\
\text { respected. }\end{array}$ & 37 & 92.5 & I0 & 100 & 3 & 7.5 & 0 & 0 \\
\hline I7 & $\begin{array}{l}\text { Students will explicitly make an } \\
\text { appointment if they require help } \\
\text { from their lecturer. }\end{array}$ & 20 & 50 & I0 & 100 & 20 & 50 & 0 & 0 \\
\hline 20 & $\begin{array}{l}\text { Teachers should be available on } \\
\text { certain days each week. }\end{array}$ & 34 & 85 & I0 & 100 & 6 & I5 & 0 & 0 \\
& & & & & & & & & \\
\end{tabular}

Table 6: Individual and cultural variations

Even if not all individual and cultural variations are considered in the curriculum, as students ( $25 \%$ ) and teachers (30\%) have observed, $92.5 \%$ of the students strongly agree that their independence should be respected. Unfortunately, the contract that Mozambican teachers sign when starting their work does not include ethical rules and even when they might be included, such rules are not readily available for teachers.

Moreover, all the UEM teachers involved in this study expect that students will explicitly make an appointment if they require help, while only half the students (50\%) believe that teachers should be available on certain days and at certain times each week. This means that some students cannot ask for assistance outside the classroom environment if teachers do not provide them with a timetable for that purpose.

In addition, some students are more confident in using their personal skills and they are also encouraged to learn through participation and interaction, using the skills of the group and valuing cooperation. Thus, some students work alone without relying on their peers while others work in groups, collaborating before and sometimes during tests. While individualistic students are more interested in academic achievement (Warring \& Huber-Warring, 2006), collectivist students tend to combine the academic with social achievements. While collectivist students depend more on contextual elements, the individualist students show more self-reliance in the academic field. In spite of that, collectivist students, who make up the majority of UEM students, are more likely to benefit from both academic and social knowledge and collaboration. Lier (1988:74) notes that interaction has an efficient effect on language learning, since it occurs in and through participation in speech events.

Although $50 \%$ of students expect teachers to be available to students both inside and outside the classroom learning environment, teachers have an extremely busy timetable (as we can see from the Focus Group answer c in the Instruments' section) and they are also expected to teach across a number of courses. This does not enable them to be always available outside the classroom learning environment for their students. 


\begin{tabular}{|c|c|c|c|c|c|c|c|c|c|}
\hline \multirow[t]{3}{*}{$\mathrm{N}^{\circ}$} & \multirow[t]{3}{*}{ Statement } & \multicolumn{8}{|c|}{ Frequency } \\
\hline & & \multicolumn{4}{|c|}{ Total Agree } & \multicolumn{4}{|c|}{ Total Disagree } \\
\hline & & $\mathrm{S}$ & $\%$ & $\mathrm{~T}$ & $\%$ & $\mathrm{~S}$ & $\%$ & $\mathrm{~T}$ & $\%$ \\
\hline 3 & $\begin{array}{l}\text { Students learn better when teach- } \\
\text { ers use both Portuguese and } \\
\text { English in the classroom. }\end{array}$ & I3 & 32.5 & 4 & 40 & I9 & $47 \cdot 5$ & 6 & 60 \\
\hline 4 & $\begin{array}{l}\text { It is effective for students to learn } \\
\text { English through English itself. }\end{array}$ & 20 & 50 & 7 & 70 & 20 & 50 & 3 & 30 \\
\hline 6 & $\begin{array}{l}\text { Students' character and knowl- } \\
\text { edge have an effect in their lean- } \\
\text { ing outcome. }\end{array}$ & I8 & 45 & 5 & 50 & 2 & 55 & 5 & 50 \\
\hline 7 & $\begin{array}{l}\text { There is no motivation for learn- } \\
\text { ing English among Mozambican } \\
\text { students. }\end{array}$ & 25 & 62.5 & 0 & o & I5 & $37 \cdot 5$ & IO & IOO \\
\hline 9 & $\begin{array}{l}\text { Reading can improve writing, } \\
\text { speaking and listening. }\end{array}$ & 37 & 92.5 & IO & I00 & 3 & $7 \cdot 5$ & 0 & 0 \\
\hline IO & $\begin{array}{l}\text { Students learn English effectively } \\
\text { when teachers show them vo- } \\
\text { cabulary similarities and differ- } \\
\text { ences between English and Bantu } \\
\text { languages. }\end{array}$ & I6 & 40 & 4 & 40 & 24 & 60 & 6 & 60 \\
\hline II & $\begin{array}{l}\text { Students learn effectively when } \\
\text { teachers show them vocabulary } \\
\text { similarities and differences be- } \\
\text { tween English and Portuguese. }\end{array}$ & I5 & 37.5 & 5 & 50 & 25 & 62.5 & 5 & 50 \\
\hline $\mathrm{I} 2$ & $\begin{array}{l}\text { Although teachers should advise } \\
\text { which readings are to be done, } \\
\text { readings are not to be read. }\end{array}$ & I4 & 35 & 0 & o & 26 & 65 & IO & IOO \\
\hline I5 & $\begin{array}{l}\text { Teachers should be available to } \\
\text { students both inside and outside } \\
\text { the classroom learning environ- } \\
\text { ment. }\end{array}$ & 36 & 90 & 8 & 80 & 4 & IO & 2 & 20 \\
\hline 2 & $\begin{array}{l}\text { Teachers have an extremely busy } \\
\text { timetable and are expected to } \\
\text { teach across a number of courses. }\end{array}$ & 37 & 92.5 & IO & IOO & 3 & 7.5 & 0 & 0 \\
\hline 9 & $\begin{array}{l}\text { Examinations are one component } \\
\text { of the learning process. }\end{array}$ & 29 & 72,5 & 7 & 70 & II & $27 \cdot 5$ & 3 & 30 \\
\hline
\end{tabular}




\begin{tabular}{|c|c|c|c|c|c|c|c|c|c|}
\hline \multirow[t]{3}{*}{$\mathrm{N}^{\circ}$} & \multirow[t]{3}{*}{ Statement } & \multicolumn{8}{|c|}{ Frequency } \\
\hline & & \multicolumn{4}{|c|}{ Total Agree } & \multicolumn{4}{|c|}{ Total Disagree } \\
\hline & & $S$ & $\%$ & $\mathrm{~T}$ & $\%$ & $S$ & $\%$ & $\mathrm{~T}$ & $\%$ \\
\hline $\mathrm{I} 2$ & $\begin{array}{l}\text { Teachers have difficulties in using } \\
\text { bantu languages because not all } \\
\text { Mozambican teachers speak all } \\
\text { Bantu languages. }\end{array}$ & 40 & IOO & 9 & 90 & 0 & 0 & I & IO \\
\hline
\end{tabular}

Table 7. Beliefs about students and learning

Although some teachers have difficulties in using Bantu languages because not all teachers speak them, there are some similarities and differences in the vocabulary of both English and Bantu Languages (Firmino, 2005). 40\% of the teachers believe that when there are similarities it is effective to point that out to the students, so that they can easily learn from what they already know in their mother tongue, whether it is Portuguese or a Bantu language. This does not mean that students learn better only when teachers switch from one language to another in the classroom, but there will be no motivation (62.5\%, point 7), if only English is used in lower classes, particularly in Mozambique, where English is learnt as the third language after the official language, Portuguese. They also believe that the use of English, Portuguese and even a Bantu language makes it easier for them to understand new and similar words, although at an advanced level it is always good practice to learn English through English itself. In fact, more than $69 \%$ of Mozambican English teachers also believe that for ELT students, learning English through English itself is more effective (students $50 \%$ and teachers $70 \%$ ) than via translation into Portuguese. This means that translation in class is only considered to be useful in the first level classes and not from upper-intermediate level upwards.

As for reading, several studies have shown that if students have good reading skills, they are better able to improve their communicative abilities, vocabulary and grammar (Hibbs, 2009), competence and a sense of self-efficacy Guthrie (2002, cited in Scharlach, 2008). In fact, if students read a text and they have to tell the story to the class, they will be improving their speaking and their listening skills. If they have to write a summary of the story they have read they are dealing with writing skills. Unfortunately, many students have not developed solid reading habits in the Portuguese language, and this has a negative influence on their reading habits in English. That is the reason why students $(35 \%)$ still believe that although teachers should advise as to which texts are to be to be read, these are not compulsory. The fact that about $65 \%$ of the technical and technological literature is only available in English at UEM (Lopes, 2004) and in most of the existing libraries in Mozambique is among the reasons why students skip reading materials. 


\begin{tabular}{|c|c|c|c|c|c|c|c|c|c|}
\hline \multirow[t]{3}{*}{$\mathrm{N}^{\circ}$} & \multirow[t]{3}{*}{ Statement } & \multicolumn{8}{|c|}{ Frequency } \\
\hline & & \multicolumn{4}{|c|}{ Total Agree } & \multicolumn{4}{|c|}{ Total Disagree } \\
\hline & & $\mathrm{S}$ & $\%$ & $\mathrm{~T}$ & $\%$ & S & $\%$ & $\mathrm{~T}$ & $\%$ \\
\hline I6 & $\begin{array}{l}\text { Teachers are not authority figures } \\
\text { and students therefore do not } \\
\text { avoid direct communication. }\end{array}$ & I9 & 47.5 & 8 & 80 & $2 \mathrm{I}$ & 52.5 & 2 & 20 \\
\hline I9 & $\begin{array}{l}\text { Teachers have to be ready to deal } \\
\text { with crowded and global class- } \\
\text { rooms. }\end{array}$ & 34 & 85 & IO & IOO & I6 & I5 & 0 & 0 \\
\hline IO & $\begin{array}{l}\text { Teachers learned English in infor- } \\
\text { mal and not in formal and public } \\
\text { schools. }\end{array}$ & 20 & 50 & 7 & 70 & 20 & 50 & 3 & 30 \\
\hline II & $\begin{array}{l}\text { Teachers are not good readers be- } \\
\text { cause they do not have the habit } \\
\text { of reading for pleasure. }\end{array}$ & 23 & 57.5 & 5 & 50 & 17 & 42.5 & 5 & 50 \\
\hline
\end{tabular}

Table 8: Beliefs about teachers and learning

Data show that teachers are authoritative given that only ( $47 \%$ ) believe that they are not. In reality, teachers should not be authoritative as such, since most classes are crowded and students ( $85 \%$ ) believe that teachers need to be ready to deal with these classes, and they also need to be a little friendly so as to be able to deal with the substantial numbers of students.

In addition, there are many private and public English teaching schools in the main cities of Mozambique, but $40 \%$ of the teachers believe that they learned English in informal settings and not in formal settings and public schools. In fact, it is common among students living in Maputo to learn English in the so-called "English Preschools".

Only half of the involved teachers (50\%) agree that Mozambican teachers are not good readers, although they reckon that they did not acquire the reading habit as students. This shows that what is missing is a Reading Strategy Instruction among Mozambican teachers, to encourage the habit of reading for pleasure. This can also be seen as the result of busy timetable and crowded classrooms, as well as the so-called turbo teachers. ${ }^{3}$ This phenomenon seems to date back many years, and teachers have been using this strategy to make sure that their income is sufficient for their monthly savings and survival. Following the turbo phenomenon is the privatization of education or the "knowledge business"

3 Turbo is a nickname for those teachers who work in more than 3 teaching institutions in order to guarantee a good salary.

4 The same teachers working at the public institutions build another private institution where they strive for better conditions and higher salaries. Sometimes, even at public universities, night shifts and courses are given for students who pay higher fees more than what they pay inside public institutions. 
Looking at the Mozambican hierarchies, we can see that leaders do not mix with their subordinates and fathers do not mix with their children (Nhapulo, 20II) and, as a result of this cultural background, teachers are not as friendly to their students as some students wish them to be. This means that often teachers become authoritative without being aware of that attitude. This attitude is due to cultural background, like the engendered hierarchies, but it is also the result of an enculturation. That is, the way a teacher deals with the classroom learning environment depends on the university/place/country where s/he did his/her Licenciatura, Master or PhD degrees, as it is clear in the Focus Group notes (d).

Therefore, in spite of differences in training countries, cultural differences and differences in learner and teacher expectations, teachers not only need to be ready to deal with multicultural, crowded and also global classrooms, but also, they need to take into consideration individual and cultural variations among their students.

\section{Limitations of the study}

The lack of previous studies on this topic in the Mozambican setting was the first limitation as the study itself is innovative in that we had to base our foundations on foreign studies and establish our own direction.

The second aspect is related to the questionnaire and its interpretation. In the questionnaire we have used the four point Lickert scale but during data analysis we felt that a five point scale could not have been a negative approach, although the use of four point Lickert scale enabled us to divide the data into two sections, agreement and disagreement. This was also a problem as sometimes it was not easy to see what percentage belonged to a simple agreement and a strong agreement in a given statement.

There were also questionnaire items that seemed to be similar or contradictory, but the fact that students and teachers reacted to them in different ways encouraged us to keep them in our analysis.

With these points in view, we believe that further studies on learner beliefs should be conducted in the Mozambican context, using a five point Lickert scale and using in particular more than one of these approaches (normative, cognitive and contextual), and exploring at greater length the relation between beliefs and individual differences as we have seen that beliefs may be derived from a group but their effect may be felt or seen in individuals classroom involvement and achievements as well.

\section{Conclusion and insights}

During the research, it was found that:

- I) Mozambican students and teachers have generally the same beliefs differing mainly in the frequency of their agreement and disagreement. Looking at total agreements and disagreements we can see that students need speaking practice and they also need to be involved in reading groups outside the classroom learning environment to improve their reading and writing skills, while simultaneously improving their speaking and listening skills which they need for their academic, social and professional purposes. 
- 2) Students believe that, although there are new textbooks and dictionaries rooted in the Mozambican reality, there is still a lack of up-to-date teaching material that fits the linguistic level of university students, as well as an effective syllabus and curriculum design that takes into consideration their beliefs, needs and cultural background. Moreover, although some of them feel that translation may still help, only English should be used as the language of instruction in advanced English classes. Therefore, resource centres, book clubs at schools, round-table projects and reading groups are required outside the classroom learning environment. So far, there is still a need for more material development activities within universities, as well as ESP material to match the different university faculties' needs.

- 3) Both teachers and students admit that there are authoritative and friendly teachers, and this has to do with Mozambican culture which is not egalitarian as such. Students also believe that teachers should be available in and outside the classroom environment, but the busy Mozambican turbo teachers are seldom available. In addition, pedagogy will therefore be more learner-centred and assessment methods will have to fit to the complexity of interrelationships which shape learner's beliefs, behaviours and attitudes if the linguistic, cognitive and social backgrounds are to be considered.

- 4) Advanced students are highly motivated to learn English, but they often lack self-confidence and do not receive sufficient reading strategy instruction applicable to their Bantu languages, Portuguese, the language of instruction in Mozambique, from which they could have acquired good reading skills. In this context, switching from one language to another, promoting reading strategy instruction, extensive reading and reading groups outside the classroom environment are believed to promote linguistic and communicative competence, as well as promoting the habit of reading among teachers and learners.

- 5) Teachers believe that they have learnt English outside the formal setting, which means that students should look for extra English classes outside the university as well. Also, crowded classrooms and busy timetables are stumbling blocks in the teaching profession, although they do not mean lack of teaching ability and experience.

\section{References}

Adjer, C. Temple \& Snow, C.E. \& Donna, Ch. (eds) (2002). What Teachers Need to Know About Language. USA: Delta Systems.

Allen, L. (1996). The evaluation of a learner's beliefs about language learning. Carleton Papers in Applied Language Studies, 13, 67-80.

Baiyinna, Wu. (20I I). An Investigation of Teacher and Learner Beliefs About English Teaching and Learning for Mongolian University Students. Chinese Journal of Applied Linguistics. 34/1, 93-110.

Barcelos, A.M.F. (2000). Understanding teachers' and students' language learning beliefs in experience: A Deweyan approach (John Dewey). Unpublished doctoral dissertation. The University of Alabama, Tuscaloosa. Benson, C. J. (1997). Final Report on Bilingual Education: Bilingual Experience external Evaluation in Mozambique (PEBIMO). Maputo: INDE.

Benson, P. \& Lor, W. (1999). Conceptions of language and language learning. System, 27(4), 459-472. 
Bernat, E., \& Gvozdenko, I. (2005). Beliefs about Language Learning: Current Knowledge, Pedagogical Implications, and New research Directions. TESL-TJ, 9/I, I-20.

Brislin, R.W. \& Tomoko, Y. (1994). Improving Intercultural Interactions: Modules for Cross-Cultural training Programme. London: SAGE Publications.

Brown, A. (2009). Students' and teachers' perceptions of effective foreign language teaching: A comparison of ideas. The Modern Language Journal, I, 46-6o.

Cagiltay, K. \& Bichelmeyer, B. (2000). Differences in Learning Styles in Different Countries. Conference paper Annual meeting of the American Education Research Association.

Celce-Murcia, M. (199I). Language Teaching Approaches: An Overview. In Teaching English as a Second Language (pp. 3-ro). New York: Heinle \& Heinle Publishers.

Chawhan, L., \& Oliver, R. (2000). What beliefs do ESL students hold about language learning? TESOL in Context, IO(I), 20-26.

Chimbutane, F.S. (2003). Education Evaluation Project: Sub-Project of Monitoring and Evaluation of Bilingual Education in Gaza. Annual Report. INDE: Maputo.

Cohen, A.D. (2000). Strategies in Learning and Using a Second Language. China: Foreign Language Teaching and Research Press.

Cortazzi, M. (2000). Languages, Cultures and Cultures of Learning in Global Classrooms. In Kam, H. W. \& Ward, C. Language in Global Context: Implications for the Language Classroom. Singapore: SEMEO Regional Language Centre.

Cortazzi, M., \& Jin, L. (1996). Cultures of learning: Language classrooms in China. In H. Coleman (Ed). Society and the language classroom (pp. 169-203). Cambridge: Cambridge University Press.

Damato S, Bonatti C, Frigo V, Pappagallo S, et al. (2005). Validation of the Clinical COPD questionnaire in Italian language. Health and Quality of Life Outcomes, 3/9.

Darlene, F. (1997). Is There a Difference among Learning Styles? US: Educational Resources Information Centre (ERIC), I-I

Dias, E.P. (1998). Linguistic Transfer and Lack of Success in Professional Courses conducted in English Language. Maputo: UEM. (unpublished graduation thesis).

Dogancay-Aktuna, S. (2005). Intercultural communication in English language teacher education. ELT Journal. Vol. 59/2, 99-107.

Dörnyei, Z. (2002). Questionnaires in second language research. Chapters I-4. Hillsdale, N. J.: Lawrence ErIbaum.

Field, K. (2000). Issues in Modern Foreign Language Teaching. London: Routledge Falmer, 3-21.

Firmino, G. (2005). A 'Questão Linguística' na África Pós-Colonial: O Caso do Português e das Línguas Autóctones em Moçambique. Maputo: Texto Editores.

Gillett, A. (1996). What is EAP? IATEFL ESP SIG Newsletter, 6, 17-23.

Hibbs, B. (2009). Reading Children's and Adolescent Literature in Two University Second Semeter Spanish Courses: An exploratory Classroom Study. Arizona Working Papers in SLA \& Teaching. 16, 27-55.

Hofstede, Geert et al. (2002). Exploring Culture: Exercises, Stories, and Synthetic Cultures. Yarmouth: Me. Intercultural Press.

Horwitz, E.oK. (1985). Surveying student beliefs about language learning and teaching in the foreign language methods course, Foreign Language Annals, I8(4), 333-340.

- (1987). Surveying student beliefs about language teaming. In A.L. Wenden \& J. Robin (Eds.), Learner strategies in language learning (pp. I19-132). London: Prentice Hall.

- (1999). Cultural and situational influences on foreign language learners' beliefs about language learning: A Review of BALLI Studies [Special Issue]. System, 27, 557-576.

- (2008). Becoming a Language Teacher: A Practical Guide to Second Language Learning and Teaching. Boston: Pearson. 
Hosenfeld, C. (2003). Evidence of emergent beliefs of a second language learner: A diary study. In P. Kalaja and A.M.F. Barcelos (Eds.), Beliefs about SLA: New research approaches, (pp. 37-55). Dordrecht: Kluwer Academic Publishers.

Hui, L. (2005). Chinese cultural schema of Education: Implications for communication between Chinese students and Australian Educators. Issues in Educational Research, 15/1, 17-38.

Jensen, E. (1998). Introduction to Brain-Compatible Learning. San Diego, CA: The Brain Store, Inc.

Kalaja, P. (2003). Research on students' beliefs about SLA within a discursive approach. In Kalaja, P., \& Barcelos, A. M. F. (Eds.), Beliefs about SLA: New research approaches (pp. 87-108). Dordrecht: Kluwer Academic Publishers.

Kennedy, P. (2002). Learning cultures and learning styles: myth-understandings about adult (Hong Kong) Chinese learners. International Journal of Lifelong Education. 21/5, 430-445.

Kern, R.G. (1995). Students' and teachers' beliefs about language learning. Foreign Language Annals, 28, $7 \mathrm{I}-92$.

Kim-Yoon, H. (2000). Learner beliefs about language learning, motivation and their relationship: A study of EFL learners in Korea. Dissertation Abstracts International, 6I (08), 304IA. (UMI No. 9983257).

Kramsch, C. (2003). Metaphor and the subjective construction of beliefs. In Kalaja, P., \& Barcelos, A.M.F. (Eds.), Beliefs about SLA: New research approaches (pp. I09-128). Dordrecht: Kluwer Academic Publishers.

Larsen-Freeman, D. \& Long, M.H. (I9gr). Theories in second language acquisition. An Introduction To Second Language Acquisition Research (Chapter 7). London: Longman.

Lo Bianco, J., Liddicoat, A.J., Crozet, C. (eds.) (1999). Striving for the Third Place: Intercultural Competence through Language Education. Melbourne: Language Australia.

Lopes, A. (1997). Language Policy: Principles and Problems. Maputo: Imprensa Universitária.

Lopes, A.J. (1999). The Language Situation in Mozambique. In Kaplan, R.B. \& Baldauf. Jr. (eds). Language Planning in Malawi, Mozambique \& Philipines. Cleredon: Multilingual Matters, 86-132.

- (2001). Language Revitalization and Reversal in Mozambique: The Case of Xiringa in Maputo. Current Issues in Language Planning. 2/2-3, 259-267.

- (2004). The Battle of the Languages: Perspectives on Applied Linguistics in Mozambique. Maputo: Imprensa Universitária.

Lier, Leo Van (1988). The classroom and Language Learner. London: Longman.

Nhapulo, M. (20II). Gender Equality Promotion Strategies \& Community Development. Maputo: University Press.

Omaggio, A.C. (1978). Successful language learners: What do we know about them? ERIC/CLL News Bulletin, May, 2-3.

Oxford, R. (1994). Language Learning Strategies: An Update. Center for Applied Linguistics) http://www.cal.org/resources/digest/oxfordor.html

- (2003). Language Learning Styles and Strategies: an overview. Learning Styles \& Strategies. Oxford: GALA.

Peacock, M. (200I). Pre-service ESL teachers' beliefs about second language learning: A longitudinal study. System, 29, 177-195.

Riley, P. (1980). Mud and stars: Personal constructs sensitization and learning. (ERIC Document Reproduction Service, No. ED20198).

Sakui, K. \& Gaies, S, J. (1999). Investigation Japanese learners' beliefs about language learning. System, 27, $473-475$.

Scharlach, T.D. (2008). START Comprehending: Students and Teachers Actively Reading Text. The Reading Teacher. $62 / \mathrm{I}, 20-3 \mathrm{I}$.

Shuell, T.J. (1986). Cognitive Conceptions of Learning. Review of Educational Research. Winter, 411-436.

Skutnabb-Kangas, T. (2002). Why should linguistic diversity be maintained and supported in Europe: some arguments. Strasbourg: Language Policy Division, $\mathrm{I}-20$. 
Sitoe, B. \& Schulz, B. (2005). Schouls Dictionary for Mozambique. Maputo: Education Development National Institute.

Thomas, L.F. \& Harri-Augstein, E.S. ( 1983$)$. The evaluation of an intelligent learning system, learning-to-learn and the CAL-Skills Trainer. (Final report, Centre for the Study of Human Learning/Applied Psychology Unit of Admiralty Marine Technology Establishment Project), Centre for the Study of Human Learning. Brunel University, Uxbridge, Middx.

Unesco. (2003). Language Vitality \& Endangerment. UNESCO Ah Hoc Group on Endangered Languages. Paris.

Victori, M. \& Lockhart, W. (1995). Enhancing metacognition in self-directed language learning. System, 23(2), 223-234.

Warring, D.F. \& Huber-Warring, T. (2006). Born in the USA, Teaching in Caracas. In Wenden, A.L (2002). Learner Development in Language Learning. Applied Linguistics, 23/1. Oxford: Oxford University Press, 32-55.

Wenden, A. (1986a). Helping language learners think about learning. English Language Journal, 40(I), 3-1 2.

- (1986b). What do second language learners know about their language learning? A second look at retrospective accounts. Applied Linguistics, 7, 186-205.

- (1987). How to be a successful language learner: Insights and prescriptions from L2 learners. In A. Wenden\& J. Rubin (Eds.), Learner strategies in language learning (pp. I03-117). London: Prentice Hall.

- (1998). Metacognitive knowledge and language learning. Applied Linguistics, 19(4), 515-537.

- (1999). An introduction to metacognitive knowledge and beliefs in language learning: Beyond the basics [Special Issue]. System, 27, 435-44I.

- (2001). Metacognitive knowledge. In Breen, M.P. (Ed.), Learner contributions to language learning. New Directions in Research (pp. 44-64). Harlow, Essex: Pearson Education Limited.

White, C. (1999). Expectations and emergent beliefs of self-instructed language learners. System, 27(4), 443-457.

William, M, \& Burden, R. (1997). Psychology for Language Teachers. A Social Constructivist Approach. Cambridge: Cambridge University Press. Yang, N, D. (1999). The Relationship between EFL learner's beliefs and learning strategy use. System, 27, 515-535.

Yang, D. (1999). The relationship between EFL learners' beliefs and learning strategy [Special Issue]. System, 27, 515-535.

Yilmaz-Soylu, M. \& Akkonyunlu, B. (2002). The Effect of Learning Strategieson achievement in Different Learning Environments. The Turkish Journal of Educational Tecchonology, 8/4, 43-50. 


\section{Appendix}

Questionnaire for students and teachers about their beliefs on English teaching and learning in Mozambique

Circle the number that corresponds to your degree of agreement with the statements listed on the left.

\begin{tabular}{|c|c|c|c|c|c|}
\hline \multirow[t]{2}{*}{$\mathrm{N}^{\circ}$} & \multirow[t]{2}{*}{ Statement } & \multicolumn{4}{|c|}{ Frequency } \\
\hline & & $\begin{array}{l}\text { Strongly } \\
\text { Agree }\end{array}$ & Agree & Disagree & $\begin{array}{l}\text { Srongly } \\
\text { Disagree }\end{array}$ \\
\hline & \multicolumn{5}{|c|}{ Beliefs about students and learning } \\
\hline I & $\begin{array}{l}\text { Mozambican students speak more } \\
\text { than one language. }\end{array}$ & 4 & 3 & 2 & I \\
\hline 2 & $\begin{array}{l}\text { Mozambican students are good } \\
\text { English language learners. }\end{array}$ & 4 & 3 & 2 & I \\
\hline 3 & $\begin{array}{l}\text { Students learn better when teach- } \\
\text { ers use both Portuguese and } \\
\text { English in the classroom. }\end{array}$ & 4 & 3 & 2 & I \\
\hline 4 & $\begin{array}{l}\text { It is effective for students to learn } \\
\text { English through English itself. }\end{array}$ & 4 & 3 & 2 & I \\
\hline 5 & $\begin{array}{l}\text { Students are good at grammar but } \\
\text { they are not fluent in speaking. }\end{array}$ & 4 & 3 & 2 & I \\
\hline 6 & $\begin{array}{l}\text { Students' character and knowledge } \\
\text { have an effect in their leaning out- } \\
\text { come. }\end{array}$ & 4 & 3 & 2 & I \\
\hline 7 & $\begin{array}{l}\text { There is no motivation for learn- } \\
\text { ing English among Mozambican } \\
\text { students. }\end{array}$ & 4 & 3 & 2 & I \\
\hline 8 & $\begin{array}{l}\text { Students are bad at reading and } \\
\text { writing. }\end{array}$ & 4 & 3 & 2 & I \\
\hline 9 & $\begin{array}{l}\text { Reading can improve writing, } \\
\text { speaking and listening. }\end{array}$ & 4 & 3 & 2 & I \\
\hline IO & $\begin{array}{l}\text { Students learn English effectively } \\
\text { when teachers show them vo- } \\
\text { cabulary similarities and differ- } \\
\text { ences between English and Bantu } \\
\text { languages. }\end{array}$ & 4 & 3 & 2 & I \\
\hline II & $\begin{array}{l}\text { Students learn effectively when } \\
\text { teachers show them vocabulary } \\
\text { similarities and differences be- } \\
\text { tween English and Portuguese. }\end{array}$ & 4 & 3 & 2 & I \\
\hline
\end{tabular}




\begin{tabular}{|c|c|c|c|c|c|}
\hline \multirow[t]{2}{*}{$\mathbf{N}^{\circ}$} & \multirow[t]{2}{*}{ Statement } & \multicolumn{4}{|c|}{ Frequency } \\
\hline & & $\begin{array}{l}\text { Strongly } \\
\text { Agree }\end{array}$ & Agree & Disagree & $\begin{array}{l}\text { Srongly } \\
\text { Disagree }\end{array}$ \\
\hline & \multicolumn{5}{|c|}{ Beliefs about students and learning } \\
\hline $\mathrm{I} 2$ & $\begin{array}{l}\text { Although teachers should advise } \\
\text { which readings are to be done, } \\
\text { readings are not to be read. }\end{array}$ & 4 & 3 & 2 & I \\
\hline I3 & $\begin{array}{l}\text { Students rely on copy and paste } \\
\text { techniques when doing reading } \\
\text { exercises. }\end{array}$ & 4 & 3 & 2 & I \\
\hline I4 & $\begin{array}{l}\text { Students expect teacher to give } \\
\text { them everything in the classroom. }\end{array}$ & 4 & 3 & 2 & I \\
\hline I5 & $\begin{array}{l}\text { Teachers should be available to stu- } \\
\text { dents both inside and outside the } \\
\text { classroom learning environment. }\end{array}$ & 4 & 3 & 2 & I \\
\hline I6 & $\begin{array}{l}\text { Teachers are not authority figures } \\
\text { and students therefore do not } \\
\text { avoid direct communication. }\end{array}$ & 4 & 3 & 2 & I \\
\hline I7 & $\begin{array}{l}\text { Students' cultural background is } \\
\text { considered in curriculum design. }\end{array}$ & 4 & 3 & 2 & I \\
\hline I8 & $\begin{array}{l}\text { Students decide on what to learn at } \\
\text { the beginning of the semester. }\end{array}$ & 4 & 3 & 2 & I \\
\hline I9 & $\begin{array}{l}\text { Teachers have to be ready to deal } \\
\text { with crowded and global class- } \\
\text { rooms. }\end{array}$ & 4 & 3 & 2 & I \\
\hline \multirow[t]{2}{*}{20} & $\begin{array}{l}\text { Teachers change their teaching ma- } \\
\text { terials whenever they wish so. }\end{array}$ & 4 & 3 & 2 & I \\
\hline & \multicolumn{5}{|c|}{ Beliefs about teachers and learning } \\
\hline I & $\begin{array}{l}\text { Mozambican teachers should } \\
\text { develop teaching materials con- } \\
\text { sidering the existing similarities } \\
\text { between Portuguese and English. }\end{array}$ & 4 & 3 & 2 & I \\
\hline 2 & $\begin{array}{l}\text { Teachers have an extremely busy } \\
\text { timetable and are expected to teach } \\
\text { across a number of courses. }\end{array}$ & 4 & 3 & 2 & I \\
\hline 3 & $\begin{array}{l}\text { Mozambican teachers should devel- } \\
\text { op teaching materials considering } \\
\text { the existing similarities between } \\
\text { Bantu Languages and English. }\end{array}$ & 4 & 3 & 2 & I \\
\hline
\end{tabular}




\begin{tabular}{|c|c|c|c|c|c|}
\hline \multirow[t]{2}{*}{$\mathrm{N}^{\circ}$} & \multirow[t]{2}{*}{ Statement } & \multicolumn{4}{|c|}{ Frequency } \\
\hline & & $\begin{array}{l}\text { Strongly } \\
\text { Agree }\end{array}$ & Agree & Disagree & $\begin{array}{l}\text { Srongly } \\
\text { Disagree }\end{array}$ \\
\hline & \multicolumn{5}{|c|}{ Beliefs about students and learning } \\
\hline 4 & $\begin{array}{l}\text { Teaching material has to be cultur- } \\
\text { ally contextualized. }\end{array}$ & 4 & 3 & 2 & I \\
\hline 5 & $\begin{array}{l}\text { Student independence is to be } \\
\text { respected. }\end{array}$ & 4 & 3 & 2 & I \\
\hline 6 & $\begin{array}{l}\text { The materials I use in the class- } \\
\text { room are suitable for Mozambican } \\
\text { advanced students. }\end{array}$ & 4 & 3 & 2 & I \\
\hline 7 & $\begin{array}{l}\text { Teachers may use Portuguese, } \\
\text { English or any Bantu language, so } \\
\text { long as students can understand } \\
\text { what they are being taught. }\end{array}$ & 4 & 3 & 2 & I \\
\hline 8 & $\begin{array}{l}\text { Teachers should teach English } \\
\text { only through English. }\end{array}$ & 4 & 3 & 2 & I \\
\hline 9 & $\begin{array}{l}\text { Examinations are one component } \\
\text { of the learning process. }\end{array}$ & 4 & 3 & 2 & I \\
\hline IO & $\begin{array}{l}\text { Teachers learned English in infor- } \\
\text { mal and not in formal and public } \\
\text { schools. }\end{array}$ & 4 & 3 & 2 & I \\
\hline II & $\begin{array}{l}\text { Teachers are not good readers } \\
\text { because they do not have the habit } \\
\text { of reading for pleasure. }\end{array}$ & 4 & 3 & 2 & I \\
\hline I 2 & $\begin{array}{l}\text { English Teachers have difficul- } \\
\text { ties in using all bantu languages } \\
\text { because not all of them speak the } \\
\text { same Bantu languages. }\end{array}$ & 4 & 3 & 2 & I \\
\hline I3 & $\begin{array}{l}\text { Teachers should encourage } \\
\text { students to be increasingly au- } \\
\text { tonomous, i.e. to facilitate student } \\
\text { independence as learners. }\end{array}$ & 4 & 3 & 2 & I \\
\hline I4 & $\begin{array}{l}\text { Teachers partake in curriculum } \\
\text { design and implementation. }\end{array}$ & 4 & 3 & 2 & I \\
\hline I5 & $\begin{array}{l}\text { Mozambican teachers should } \\
\text { develop teaching material consid- } \\
\text { ering the students current level of } \\
\text { proficiency. }\end{array}$ & 4 & 3 & 2 & I \\
\hline
\end{tabular}




\begin{tabular}{|c|c|c|c|c|c|}
\hline \multirow[t]{2}{*}{$\mathbf{N}^{\circ}$} & \multirow[t]{2}{*}{ Statement } & \multicolumn{4}{|c|}{ Frequency } \\
\hline & & $\begin{array}{l}\text { Strongly } \\
\text { Agree }\end{array}$ & Agree & Disagree & $\begin{array}{l}\text { Srongly } \\
\text { Disagree }\end{array}$ \\
\hline & \multicolumn{5}{|c|}{ Beliefs about students and learning } \\
\hline I6 & $\begin{array}{l}\text { Teachers think that students have } \\
\text { fewer opportunities for practicing } \\
\text { their speaking skills. }\end{array}$ & 4 & 3 & 2 & I \\
\hline 17 & $\begin{array}{l}\text { Students will explicitly make an } \\
\text { appointment if they require help } \\
\text { from their lecturer. }\end{array}$ & 4 & 3 & 2 & I \\
\hline I8 & $\begin{array}{l}\text { It doesn't matter what materials } \\
\text { teachers use as long as the level fits } \\
\text { to students linguistic level. } \\
\end{array}$ & 4 & 3 & 2 & I \\
\hline I9 & $\begin{array}{l}\text { Teachers expect students to speak } \\
\text { only English in the classroom. }\end{array}$ & 4 & 3 & 2 & I \\
\hline 20 & $\begin{array}{l}\text { Teachers should be available on } \\
\text { certain days and each week. }\end{array}$ & 4 & 3 & 2 & I \\
\hline
\end{tabular}

